\title{
The Future of European Labour Law
}

\section{Introduction}

The future of the European project to a great extent will depend on the fact whether it can provide social justice throughout the EU. The need for improving the "European social dimension", to take up Jacques Delors' well known formula, as a tool for the people to identify themselves with the European project has never been more urgent than it is today. In this context it is of utmost importance to know whether European labour law can provide conditions which help to promote this ambitious goal.

The Chapter on Solidarity of the Charter of Fundamental Rights of the EU (CFR) guarantees a whole catalogue of social rights, among them for every worker "the right to working conditions which respect his or her [...] dignity" (Art. 31 par. 1 CFR). And according to the latest version of the Treaty the European Union "in defining and implementing its policies and activities shall take into account requirements linked to the promotion of a high level of employment, the guarantee of adequate social protection and the fight against social exclusion" (Art. 9 TFEU). This sounds very promising.

However, looking at the situation particularly in the member states of the Euro zone the assessment turns out to be totally different. In the context of the austerity measures fighting the crisis' mechanisms were developed leading particularly in the countries of Southern Europe to redundancy of employees especially in the public sector, to a general reduction of wages and pensions up to a significant extent, to a decrease of minimum wages, to deregulation of protective labour and social security standards and to a dismantling of collective bargaining. This is the result of actual EU policy in cooperation with the International Monetary Fund ${ }^{1}$.

* Prof. Dr. Dr. h.c. mult. Institut fuer Arbeitsrecht J.W. Goethe University in Frankfurt. President of the International Industrial Relations Association (IIRA) 2000-2003.

${ }^{1}$ For a comprehensive assessment see I. Schoemann, Labour law reforms in Europe: adjusting employment protection legislation for the worse?, European Trade Union Institute, working paper 2014.02 . 
There is no need to go into more details of the actual situation in many member states to show a dramatic discrepancy between the actual policy promoted by the EU and the heroic language of the texts of the CFR and the Lisbon Treaty. Therefore, it has to be asked whether these texts are mere lip service or a source of hope and what realistically can be expected for the future of labour law in the EU.

At first glance the situation for labour law in the EU seems to be promising: with the exception of "pay, the right of association, the right to strike or the right to impose lock outs" (Art. 153 par. 5 TFEU) there is comprehensive legislative power for labour law and the legislative procedure in most cases only requires qualitative majority. The number of Directives in individual labour law and in the area of workers' participation is impressive ${ }^{2}$, even if still fragmentary and unsystematic. However, a second look, as will be shown, leads to more scepticism.

\section{Perspectives for further "hard law"}

Evidently, legislation cannot be expected for the topics which still are excluded from the legislative power of the EU. Of course, theoretically all these topics could be included into the EU's legislative power by amendment of the Treaty. In particular the trade unions fight for such an inclusion. They point to the fact that these topics are covered by the CFR. These fundamental rights according to the Charter are to be promoted by the EU. But if the EU has no power to legislate, it cannot live up to the expectations created by the CFR. In spite of this very convincing argument it is very unlikely that the Treaty will be amended in this direction. This would need a consensus of all 28 Member States which is difficult to imagine for the foreseeable future.

In spite of the comprehensive legislative power there are many obstacles for further legislation. This is first of all due to the fact that the interests of the member states in the EU of 28 have become so heterogeneous that it is very unlikely to get even a qualified majority for a piece of legislation. It is understandable that low wage countries want to use lower labour standards as a competitive advantage in comparison to high wage countries. Therefore, it may well be doubted whether today it still would be possible to get a majority for something like the Posted Workers Directive $^{3}$ as it was the case in 1996 . The rather long debate on the relatively

2 See M. Weiss, Introduction to European Labour Law: European Legal Framework, EU Treaty Provisions and Charter of Fundamental Rights, [in:] M. Schlachter (ed.), EU Labour Law, Kluwer, Dordrecht 2015, 3 (17-22).

${ }^{3}$ Directive 96/71/EC of 16 December 1996, OJ 1997, L 18/1. 
modest Directive on the Enforcement of the Posted Workers Directive illustrates very well the difficulty for even minor legislation ${ }^{4}$.

But it is not only the conflict of interests between the Member States which creates difficulties for legislation in the area of labour law. Perhaps as important is the fact that the Lisbon Treaty by a Protocol on the Application of the Principles of Subsidiarity and Proportionality has given these principles such an enormous significance that legislation on controversial issues has become almost impossible. Formerly it was sufficient that the Commission gave reasons to justify its view that the principles of subsidiarity and proportionality have been respected. Now a complicated procedure is established in reference to subsidiarity and proportionality which gives national Parliaments significant power to prevent legislation by forcing the Commission to even further justify its proposal. It may well be predicted that national Parliaments will be inclined to take use of this possibility and that afterwards it will be psychologically extremely difficult for the Commission to overrule the intervention by national Parliaments. Therefore, the expectation for legislation in such a controversial area as labour law may be to a great extent a futile hope in the future.

The integration of the social partners into the legislative machinery will not make a difference. Of course, if they reach an agreement the pressure on the Council to turn it into a Directive cannot be denied. However, it has to be understood that the social partners in trying to reach such an agreement have no means but to put pressure on each other. Therefore, they very seldom have succeeded in the past. And there is no likelihood that they will do it in the future. Therefore, there is not much hope in the legislative potential of the social partners ${ }^{5}$.

In short and without going into further details: further hard law in the area of labour law realistically cannot be expected, at least not to a significant extent. The question, therefore is whether there are alternatives.

\section{Soft-Law as Alternative?}

\subsection{Voluntary Framework Agreements?}

The European social partners are entitled to conclude so called voluntary agreements to be implemented "in accordance with the procedures and practices specific to management and labour and the Member States" (Art. 155 par. 2 TFEU). Examples for such voluntary agreements

${ }^{4}$ Directive 2014/67/EU of 15 May 2014, OJ 2014, L 159/11.

${ }^{5}$ For details see M. Weiss, The European Social Dialogue, "European Labour Law Journal" 2011, p. 155. 
on inter-professional level are the framework agreements on telework (2002), on stress at the workplace (2004), on harassment in the workplace (2006), on violence in the workplace (2009) and on inclusive labour markets (2010).

These agreements are not legally binding for third parties. They are merely an offer for the actors on national scale to give them some guidance and to enrich their imagination. Or to put it differently: they are to be understood as a European input intending better coordination of collective bargaining on national scale by offering ideas on how to cope with specific problems. The national actors are supposed to reflect on the basis of these framework agreements. This implies that the European actors have no choice but to convince the national actors of the advantages of the content of the framework agreement. Only close and continuous communication offers a chance of success. This form of vertical communication is of utmost importance for the growth of real European actors of both sides of industry: a step towards a European collective bargaining system sometime in the future.

There is not only an inter-professional but also a sectoral social dialogue for the different branches of activity ${ }^{6}$. The structure of the sectoral social dialogue is essentially the same. Here the confederations of trade unions and employers associations of specific branches of activity are put together. In the meantime there are European social dialogues for $40 \mathrm{sec}-$ tors. So far the sectoral social dialogue was not very successful in producing framework agreements. They are still a rarity. The important aspect is that the sectoral dialogue has enormous potential in two ways. First it may help in an informal way to better coordinate collective bargaining in the Member States. And secondly it may be a helpful setting to improve the vertical dialogue between national and European actors in order to build up a multi-level-structure for all the sectors.

If bargaining patterns on European level are analysed, the European Works Councils must be included. Even if their role according to the respective Directive is limited to information and consultation, they have developed dynamics of their own and gone far beyond information and consultation towards negotiations, leading to agreements, in particular so called solidarity agreements in case of restructuring in order to share the burden imposed by the restructuring measure on the employees. The legal effect of these agreements is still unclear ${ }^{7}$. Since, however,

${ }^{6}$ See B. Keller, Social Dialogues at sectoral Level. The neglected Ingredient of European Industrial Relations, [in:] B. Keller, H.W. Platzer (eds), Industrial Relations and European Integration, Ashgate, Aldershot 2003, p. 30.

7 For a comprehensive assessment see E. Heimann, Substanzielle Vereinbarungen Europaeischer Betriebsraete: Praxis und Recht, Lang, Bern 2014. 
the bodies of workers' representation of the subsidiaries in the different Member States as well as national trade unions and their European confederations normally take part in the elaboration of such agreements, they are considered to be a product of a joint effort and, therefore, are respected in practice. Since in this context the interaction between national and European actors is far more developed than in the context of the inter-professional and sectoral social dialogue, the EWC pattern might be somehow the forerunner for a system of European collective agreements, of course confined to the respective groups of undertakings.

In short: The complex structure of collective negotiations on European level should not be underestimated. However, it cannot replace the lack of legislation.

\subsection{The Open Method of Coordination (OMC)?}

The OMC has been developed in the context of the European Employment Policy (EEP) in the Amsterdam Treaty ${ }^{8}$. Since then it has become the favourite strategy of the EU in social policy. According to the OMC the genuine competence of the member states remains uncontested. The EU merely is supposed to encourage co-operation between member states, to support and, if necessary, complement their action. It is mainly based on the idea that best practices as discovered in one country may be imitated by other countries, thereby leading to social progress. Instead of regulation by way of legislation the EU only tries to put soft pressure on the Member States, leaving them the task to regulate. This method, however, runs into difficulties if the gap of the economic situation between Member States is too big to allow for similar remedies. Then the capacity of OMC is quickly exhausted.

\subsection{Lisbon Strategy and Europe 2020?}

Since the beginning of the new century the EU has tried to combine $\mathrm{OMC}$ with specific goals to be reached. The first expression of this new approach was the Lisbon strategy launched in 2000 for the EU "to become the most dynamic and competitive knowledge-based economy in the world by 2010 capable of sustainable economic growth with more and better jobs and greater social cohesion and respect for the environment". A whole set of ambitious targets for 2010 were listed up, among them targets for employment rates and for full employment. The concepts for reaching these goals were put in vague notions as are "flexicurity" or "employability".

${ }^{8}$ For the development of EEP see J. Goetschy, European Employment Policy since the 1990s, [in:] B. Keller, H.W. Platzer (eds), Industrial Relations..., p. 137. 
However, soon it turned out that the strategy was much too complex, that it was lacking a clear division of tasks between EU and member states and that there was no really functioning governance structure ${ }^{9}$. Therefore, the strategy was modified and re-launched in 2005. Of great importance were country specific recommendations. They were meant to help the Member States to better realize the objectives in their national reform programs. The OMC as a mutual learning strategy was the underlying philosophy of the whole exercise.

The Lisbon strategy has, of course, not reached its goals but been replaced by the new agenda "Europe 2020", a "strategy for smart, sustainable and inclusive growth" ${ }^{\prime 10}$ which focuses on five goals to be reached by so-called flagship initiatives. In essence it is nothing else but a slimmed Lisbon strategy in new clothes. There is still the reference to the flexicurity agenda, to new forms of work-life balance, to the problem solving potential of social dialogue at all levels and to the European qualification framework. The new strategy remains to a great extent within the old paths.

Whether it makes sense to set again such ambitious targets in view of the budgetary problems some countries in the Euro Zone and beyond are struggling with, may well be doubted. Taken all these soft law strategies together, the perspectives for the future of European labour law do not seem to be very promising. The role of the EU is reduced to be at its best a promoter and coordinator of reform debates within the member states. Where this discourse will end up is totally uncertain.

\section{The Court of Justice of the EU (CJEU)?}

If hope cannot be put on legislation and only to a very limited extent to soft law, the question arises what the role of the CJEU could be. Of course, courts only can act on the basis of the existing European law. But the CJEU in the past often has proved to be a body strengthening and widening European law, including labour law. For example It has to be remembered that the wording of the Treaty allows limitations of the freedom of services only "on grounds of public policy, public security and public health" (Art. 52 par. 1 TFEU). Nevertheless, the CJEU has allowed restrictions if there is an urgent need in view of the public interest. And it has expressly put the protection of workers under this label ${ }^{11}$.

${ }^{9}$ For an assessment of the Lisbon Strategy see the report of the High Level Group chaired by W. Kok, Facing the Challenge: The Lisbon Strategy for Growth and Employment, Luxemburg 2004.

${ }_{10}$ COM (2010) 2020 final.

${ }^{11}$ Starting with Rush Portuguesa Lda v. Office National d'Immigration of 27 March 1990 - C-113/89, ECR 1990, 1417. 
The CJEU has developed this case law in reference to minimum standards for posted workers. Only, thereby, the Directive on Posted Workers could be brought in line with the Treaty. But the CJEU had to make sure that case law beyond the wording of the Treaty does not go too far. Otherwise the Court's legitimacy might be endangered. Therefore, only incremental steps were possible. This explains the CJEU's perhaps too cautious rulings in Viking ${ }^{12}$, Laval ${ }^{13}$, Rueffert ${ }^{14}$ and Luxemburg ${ }^{15}$ for which the Court was heavily opposed ${ }^{16}$ in particular by those who did not fully understand the structure of the Treaty.

However, in the meantime the position of the CJEU has improved significantly. Since the Lisbon Treaty has made the CFR legally binding the CJEU is no longer forced to construct fundamental rights by referring to all kind of international and national sources. The simple recourse to the Charter now provides the legitimacy the Court needs The CJEU now has even the possibility to make sure that the secondary European law is interpreted in line with the Charter and it even can declare secondary law null and void if it violates fundamental rights. And here the fact that fundamental social rights are embedded in the Charter becomes important.

The CJEU has already clarified that the scope of application of the CFR has a wide range ${ }^{17}$. In reference to labour law it should be seen that the CJEU is bound by the interpretation given by the European Court of Human Rights (ECHR):

"Insofar as this Charter contains rights which correspond to rights guaranteed by the Convention for the Protection of Human rights and Fundamental Freedoms, the meaning and scope of those rights shall be the same as those laid down by the said Convention..." (Article 52 par. 3 CFR)

This is particularly important in view of the new case law on freedom of association and on the right to strike ${ }^{18}$ (Art. 11 of the Convention).

Not only the CFR but also the Lisbon Treaty with the already mentioned Art. 9 TFEU justifies hope for labour law. Now the CJEU can give

${ }^{12}$ International Transport Workers' Federation, Finnish Seamen's Union v. Viking Line ABP of 11 December 2007 - C 438/05, ECR 2007, 779.

${ }^{13}$ Laval un Partneri Ltd v. Svenska Byggnadsarbetareförbundet of 18 December 2007 - C 341/05, ECR 2007, 11767.

${ }^{14}$ Rueffert Dirk v. Land Niedersachsen of 3 April 2008 - C 346/06, ECR 2008, 4323.

${ }^{15}$ Commission v. Grand Duchy of Luxembourg of 19 June 2008 - C 31/06, ECR 2008, 4323.

${ }^{16}$ See for example J.E. Dolvik, J. Visser, Free movement, equal treatment and workers' rights: can the European Union solve its trilemma of fundamental principles?, "Industrial Relations Journal" 2009, p. 491.

17 Case C-617/10 Akerberg Fransson of 26 February 2013, EU: C 2013, 105.

${ }_{18}$ See in particular ECHR, Grand Chamber, Demir and Baykara v. Turkey, judgment of 12 November 2008 (application no. 34503/97). 
the social dimension more weight in its judgments without fearing loss of legitimacy. This new article in connection with the fundamental social rights in the Charter is a solid pillar of orientation for the CJEU. Of course, it is uncertain how the Court will use this opportunity. However, in view of its attitude in the past optimism seems to be justified. So far no clear and consistent strategy of the CJEU on how to use the instrument of fundamental social rights is yet developed. But at least there are already signs into the right direction.

\section{Enhanced Cooperation}

In a situation where the necessary majority for legislation is rather unlikely, enhanced cooperation might be an option. Art. 20 TEU in connection with Art. 326 to 334 TFEU contain a rather complicated mechanism to be observed for this strategy. In spite of this complexity it has already three times ${ }^{19}$ taken the obstacles embedded in the Treaties. In essence enhanced cooperation means that a group of at least nine member states "within the framework of the Union's non-exclusive competences", as it is the case in labour law, may make use of the EU's institutions and exercise those competences. The idea is "to further the objectives of the Union, protect its interests and to reinforce its integration process" (Art. 20 par. 1 TEU). Any member state can participate in this strategy. The final decision is made by the Council where only representatives of the member states participating in enhanced cooperation have a voting right, even if all members are entitled to participate in the Council's deliberations. The acts adopted in the framework of enhanced cooperation are binding only the participating member states. The competences, rights and obligations of the non-participating member states are to be respected. Those member states shall not impede the implementation by the participating member states.

The procedure to be followed is regulated in Art. 328 to 331. It is important to stress that enhanced cooperation is not merely an inter-governmental strategy but takes place within the legal framework of the EU. However, this option by necessity leads to an EU of different speeds Whether

${ }^{19}$ Council Decision 2010/405/EU of 12 July 2010 and Council Regulation 1259/2010/ EU of 20 December 2010 on enhanced cooperation in the area of the law applicable to divorce and legal separation, OJ 2010, L 189/12 and L 343/10; Council Decision 2011/167/EU of 10 March 2011, Regulation 1257/2012/EU of 17 December 2012 and Council Regulation $1260 / 2012 / E U$ on enhanced cooperation in the area of the creation of unitary patent protection, OJ 2011, L 76/53, OJ 2012, L 361/1 and L 361/89; Council Decision 2013/52/EU of 22 January 2013 on enhanced cooperation in the area of financial transaction tax, OJ 2013, L 22/11. 
on the long run these differences of speed will be equalised and whether the non-participating member states eventually will join in, remains to be an open question. It is not surprising that some countries have tried to oppose enhanced cooperation ${ }^{20}$ as being potentially dangerous for their national interests. The fact that the CJEU ${ }^{21}$ rejected this opposition does not mean that enhanced cooperation is an uncontested strategy.

\section{Conclusion}

The search for elements which may serve as basis for a prognosis on how the future of European labour law will be, has turned out to be rather difficult. Of course, compared to the beginning of the European project where social policy was not on the agenda of the European Economic Community (EEC), much progress has been made up to now. The legal framework has significantly changed and the European legislator has produced quite remarkable results. However, European labour law still is in a somehow rudimentary stage, remaining a mere fragment. The perspectives for the future are rather mixed. Further legislation for many reasons has become more or less unlikely. There are quite a few alternative strategies putting soft pressure on the relevant actors in the Member States. The magic formula has become the OMC. The merit of initiating and maintaining this discourse is not to be denied. However, It is very unlikely that this permanent discourse on the long run will have the effect to produce a floor of labour rights throughout the EU. The responsibility after all is put on the shoulders of the member states. Their economic and social situation is too diverse to expect coordinated reforms. Of course, the spill-over effects of the vertical communication in the inter-professional and sectoral social dialogues should not be underestimated. This could be on the long run the nucleus for a proper European collective bargaining system. However, this is not something for the foreseeable future. It is still far away.

The light in the dark seems to be the CJEU which in view of the CFR and in view of the new framework introduced by the Lisbon Treaty has the possibility to act on a new platform. However, even if the Court uses its possibilities to their full extent, this mainly means strengthening the already existing pattern of European labour law. Significant innovations are rather unlikely.

Enhanced cooperation might be a promising strategy to promote European labour law. However, this strategy - at least in a short term per-

${ }^{20}$ Italy and Spain in reference to the creation of unitary patent protection.

${ }^{21}$ Judgment in Spain v. Council C-274/11 and 295/11 of 16 April 2013, EU: C 2013, 240. 
spective - would lead to different speeds within the EU. Whether this on the long run promotes or hinders European integration, is an open question.

\section{Bibliography}

Dolvik J.E., Visser J., Free movement, equal treatment and workers' rights: can the European Union solve the trilemma of fundamental principles?, "Industrial Relations Journal" 2009, vol. 491.

Goethschy J., European Employment Policy since the 1990s, [in:] B. Keller, H.W. Platzer (eds), Industrial Relations and European Integration, Ashgate, Aldershot 2003.

Heimann E., Substanzielle Vereinbarungen Europaeischer Betriebsraete: Praxis und Recht, Lang, Bern 2014.

Kok W., Facing the Challenge: The Lisbon Strategy for Growth and Employment, Luxemburg 2004.

Keller B., Social Dialogues at sectoral level, The neglected Ingredient of European Integration, [in:] B. Keller, H.W. Platzer (eds), Industrial Relations and European Integration, Ashgate, Aldershot 2003.

Schoemann I., Labour law reforms in Europe: adjusting employment protection legislation for the worse?, Brussels: ETUI working-paper 2014.02.

Weiss M., The European Social Dialogue, "European Labour Law Journal" 2011, vol. 155.

Weiss M., Introduction to Labour Law: European Legal Framework, EU Treaty Provisions and Charter of Fundamental Rights, [in:] M. Schlachter (ed.), EU Labour Law, Kluwer, Dordrecht 2015, 3.

\section{Przyszłość europejskiego prawa pracy}

\section{Streszczenie}

Traktat Europejskiej Wspólnoty Gospodarczej opierał się na minimalistycznym podejściu do polityki socjalnej, pozostawiając ją głównie Państwom Członkowskim. Podejście to uległo z czasem znaczącej zmianie. Obecnie Unia Europejska ma niemal wszechstronne upoważnienie do normowania prawa pracy. W znaczącym zakresie jest to możliwe drogą kwalifikowanej większości. W proces legislacyjny zostali włączeni partnerzy społeczni. Socjalne prawa podstawowe istotnie zwiększają legitymację unijnej polityki socjalnej. Wydano znaczną liczbę dyrektyw dotyczących prawa pracy.

Niniejszy tekst wyjaśnia, dlaczego pomimo to trudno spodziewać się kolejnych aktów „twardego" prawa. Wskazuje także, że rozwinięte na poziomie Unii Europejskiej strategie miękkiego prawa nie mogą wypełnić istniejących luk. Najwięcej nadziei na postęp można pokładać w Trybunale Sprawiedliwości UE. Jednakże nie należy spodziewać się istotnych innowacji ze strony Trybunału. Obiecująca, lecz bardzo ryzykowna, strategią mogłaby być rozszerzona współpraca. 